\title{
PASAR MODAL SYARIAH
}

FITRIANI PUTRI AP

Perbankan Syariah

Fakultas Ekonomi dan Bisnis Islam

UNIVERSITAS ISLAM NEGERI ALAUDDIN MAKASSAR

fitryatapukan98@gmail.com

\begin{abstract}
ABSTRAK
The theme of the article is based on economic principles Islam. The purpose of writing the article is: to

analyze the Sharia in BEI exchange offer. Research is the study of literature. The index of sharia has become a part or the instrument in capital market transactions. Any securities that enter the Islamic capital market flows through a rigorous selection on sharia indekk that JII (Jakarta Islamic Index). The selection is part of the bidding process before the Islamic securities offered to investors through the capital market. Among the sharia always dimanati index at the level of investors were shares of sharia, Islamic mutual funds, Islamic bonds (Sukuk) which is a part that can not be separated in capital market transactions. The institute is a precondition towards Islamic securities with principal business does not conflict with Islamic law, as stated in a fatwa DSN-MU. In the presence Index sharia, the Islamic banks, Takaful and other Islamic financial institutions have alternatives to invest their funds and distribute their profits to their clients. Keywords: JII, Sharia Stocks, Bonds, Mutual Funds Sharia.
\end{abstract}




\section{PENDAHULUAN}

Istilah pasar biasanya digunakan istilah bursa, exchange dan market. Sementara untuk istilah modal sering digunakan istilah efek, securities, dan stock. Pasar modal menurut UU No. 8 tahun 1995 tentang pasar modal Pasal 1 ayat (12) adalah kegiatan yang bersangkutan dengan Penawaran Umum dan Perdagangan Efek, Perusahaan public yang berkaitan dengan efek yang diterbirkannya, serta lembaga dan profesi yang berkaitan dengan efek. Sedangkan yang dimaksud dengan efek pada Pasal 1 ayat (5) adalah surat berharga, yaitu surat pengakuan utang, surat berharga komersial, saham, obligasi, tanda bukti utang, unit penyertaan kontrak investasi kolektif, kontrak berjangka atas efek, dan setiap derivative dari efek. Pasar modal dikenal juga dengan nama bursa efek.

Bursa efek menurut Pasal 1 ayat (4) UU No. 8 Tahun 1995 tentang Pasar Modal adalah pihak yang menyelenggarakan dan menyediakan sistem dan atau sarana untuk mempertemukan penawaran jual dan beli efek pihak pihak lain dengan tujuan memperdagangkan efek diantara mereka. Sehingga dengan

demikian hanya ada satu pelaksanaan bursa efek di Indonesia, yaitu BEI. Definisi pasar modal dalam arti luas adalah pasar konkret atau abstrak yang mempertemukan pihak yang menawarkan dan yang memerlukan dana jangka panjang, yaitu jangka satu tahun ke atas. Pasar modal (capital market) adalah pasar keuangan untuk Dana dana jangka panjang dan merupakan Pasar yang konkret. Pasar modal syariah adalah pasar modal yang seluruh mekanisme kegiatannya terutama mengenai emiten, jenis efek

yang diperdagangkan dan mekanisme perdagangannya telah sesuai dengan perinsip -prinsip syariah. Sedangkan yang dimaksud dengan efek syariah adalah efek sebagaimana dimaksud dalam peraturan perundang-undangan di bidang pasar modal yang akad, pengelolaan peruasahaan, maupun cara penerbitannya memenuhi Prinsip prinsip syariah. 
Fungsi Pasar Modal Syariah Pasar modal berperan menjalankan dua fungsi secara simultan berupa fungsi ekonomi dengan mewujudkan pertemuan dua kepentingan, yaitu pihak yang memiliki kelebihan dana dengan pihak yang memerlukan dana, dan fungsi keuangan dengan memberikan kemungkinan dan kesempatan untuk memperoleh imbalan bagi pemilik dana melalui investasi. Pada fungsi keuangan, pasar modal berperan sebagai sarana bagi pendanaan usaha atau sebagai sarana bagi perusahaan untuk mendapatkan dana dari masyarakat pemodal (investor). Dana yang diperoleh dari pasar modal dapat dipergunakan untuk pengembangan saham, ekspansi, penambahan modal kerja dan lainlain.Sedangkan pada fungsi yang kedua pasar modal menjadi sarana bagi masyarakat untuk berinvestasipada instrumen keuangan seperti saham, oligasi, reksadana, dan lainlain. Dengan demikian, masyarakat dapat menempatkan dana yang dimilikinya sesuai dengan karakteristik keuntungan dan risiko masing masing instrumen. 


\section{PEMBAHASAN}

Fungsi pasar modal syariah menurut Metwally (Rifai, 2009:535):

1. Memungkinkan bagi masyarakat berpartisipasi dalam kegiatan bisnis dengan memperoleh bagian dari keuntungan dan risikonya.

2. Memungkinkan para pemegang saham menjual sahamnya guna mendapatkan likuiditas.

3.Memngkinkan perusahaan meningkatkan modal dari luar untuk membangun dan mengembangkan link produksinya.

4.Memisahkan operasi kegiatan bisnis dari fluktuasi jangka pendek pada harga saham yang merupakan ciri umum pada pasar modal konvensional.

5.Memungkinkan investasi pada ekonomi itu ditentukan oleh kinerja kegiatan bisnis sebagaimana tercermin pada harga saham.

Karakteristik Pasar Modal Syariah Menurut Mokhtar Muhammad Metwally (Rifai, 2009) karakteristik pasar modal syariah adalah:

1. Semua saham harus diperjual belikan pada bursa efek.

2. Bursa perlu mempersiapkan pasca perdagangan dimana saham dapat diperjualbelikan melalui pialang.

3. Semua perusahaan yang mempunyai saham yang dapat diperjualbelikan di bursa efek diminta menyampaikan informasi tentang perhitungan (account) kentungan dan kerugian serta neraca keuntungan kepada komite manajemen bursa efek, dengan jarak tidak lebih dari tiga bulan sekali.

4.Komite manajemen menerapkan harga saham tertinggi (HST) tiap tiap perusahaan dengan interval tidak lebih dari tiga bulan sekali.

5. Saham tidak boleh diperjual belikan dengan harga lebih tinggi dari HST .

6. Saham dapat dijual dengan harga dibawah HST.

7.Komite manajemen harus memastikan bahwa semua perusahaan yang terlibat dalam bursa efek itu mengikuti standar akuntansi syariah.

8.Perdagangan saham mestinya hanya berlangsung dalam satu minggu periode perdagangan setelah menentukan HST

9.Perusahaan hanya dapat menerbitkan saham baru dalam periode perdagangan dengan harga HST. pinsip yariah di pasar modal. 
Prinsip prinsip syariah di pasar modal adalah prinsip prinsip hukum Islam dalam kegiatan dibidang pasar

modal berdasarkan fatwa Dewan Syariah Nasional Majelis lama Indonesia (DSNMUI), baik fatwa yang telah ditetapkan dalam peratuan Bapepam dan LK, maupun fatwa yang telah diterbitkan sebelum ditetapkannya peraturan Bapepam dan LK. Dari segi instrumen, dibandingkan dengan pasar modal konvensional, pasar modal syariah memiliki karakteristik yang unik. Segala jenis sekuritas yang menawarkan pemasukan yang sudah ditentukan di awal (predetermined fixedincome) tidak diperbolehkan dalam Islam karena termasuk riba. Dengan demikian semua instrument yang mengandung riba (interest bearing securities) baik jangka panjang (long term) maupun jangka pendek (short term) akan masuk dalam daftar investasi yang tidak sah. Masuk juga dalam kategori ini antara lain, preference stock, debentures, treasury securities and consul, dan commercial papers, obligasi.

konvensional, medium term notes, dan interest rateswap, sertifikat deposito konvensional, dan report surat utang konvensional. Sedangkan instrument keuangan yang berada dalam gray area (questionable) karena dicurigai gharar meliputi produk produk derivative, seperti forward, futures, dan juga options. Yang dibolehkan baik secara penuh atau dengan catatan meliputi saham (stocks) dan obligasi syariah (Islamic bonds/sukuk), sekuritas pemerintah berbasis bagi hasil dan surat berharga lain yang akadnya sesuai dengan prinsip syariah.

\section{Saham Syariah}

Saham atau stocks adalah surat bukti atau tanda kepemilikan bagian modal pada suatu perusahaan terbatas. Dengn demikian sipemilik saham merupakan pemilik perusahaan. Semakin besar saham yang dimilikinya, maka semakin besar pula kekuasaannya di perusahaan tersebut. Keuntungan yang diperoleh dari saham dikenal dengan dividen, rights, dan capital gain. Saham syariah adalah serifikat yang menunjukan bukti kepemilikan suatu perusahaan yang diterbitkan oleh emiten yang kegiatan usaha maupun cara pengelolaannya tidak bertentangan dengan prinsip syariah.

Dalam prinsip syariah, penyertaan modal ke dalam dilakukan pada perusahaan yang tidak melanggar prinsip syariah yang dilakukan berdasarkan akad musyarakah dan mudahrabah. Akad musyarakah umumnya dilakkan pada saham privat, sedangkan akad mudhrabah pada saham perusahaan publik. Di Indonesia penyertaan modal diwujudkan berupa pembentukan indeks 
saham yang memenuhi prinsip syariah. Dalam hal ini, di BEI terdapat Jakarta Islamic Indeks (JII) yang merupakan 30 saham yang memenuhi kriteria syariah yang ditetapkan DSN.

2. Obligasi Syariah (Sukuk)

Obligasi secara konvensioal adalah merupakan bukti utang dari emiten yang dijamin oleh penanggung yang mengandung janji pembayaran bunga atau janji lainnya serta pelunasan pokok pinjaman yang dilakukan pada tanggal jatuh tempo. Disini obligai merupakan instrumen utang bagi perusahaan yang hendak memperoleh modal. Sedangkan obligasi syariah adalah surat berharga jangka panjang berdasarkan prinsip syariah yang dikeluarkan emiten kepada pemegang obligasi syariah yang mewajibkan emiten untuk membayar pendapatan kepada pemegang sukuk berupa bagi hasil/margin/fee. Perbedaan pokok antara sukuk dengan obligasi syariah adalah berupa konsep imbalan dan bagi hasil sebagai penggganti bunga, adanya transaksi pendukung berupa asset yang menjadi dasar penerbitan sukuk dan akad berdasarkan prinsip syariah.Obligasi syariah ada diatur dalam fatwa DSN-MUI antara lain tentang Obligasi Syariah Mudharaba, Obligasi Syariah Mudharabah Konversi. Beberapa jenis sukuk yang telah dikenal scara internasional yaitu sukuk ijarah, sukuk mudharabah, sukuk musyarakah, sukuk istisna'. Ada juga Obligsi Syariah Mudharabah Konversi antara lain sukuk korporasi, surat berharga syariah negara.

\section{Reksa Dana Syariah}

Reksa Dana Syariah adalah reksadana yang beroperasi menurut ketentuan dan pirinsip syariah Islam, baik dalam bentuk akad antara pemodal sebagai pemilik harta dengan manajer investasi begitu pula pengelolaan adanya invesasi sebagai wakil shahib al mal, maupun antara Manajer Investasi dengan pengguna investasi.

\section{Efek Beragun Aset Syariah}

Efek beragun Aset Syariah adalah efek yang diterbitkan oleh kontrak investasi kolektif EBA Syariah yang portofolionya terdiri dari asset keuangn berupa tagihan yang timbul dari surat berharga komersial, tagihan yang timbul dikemudian hari, jal beli pemilikan asset fisik oleh lembaga keuangan, Efek bersifat invesasi yang dijamin pemerintah, sarana peningkatan investasi/arus kas serta aset keuangan setara, yang sesuai dengan prinsip syariah.

5. Hak Memesan Efek Terlebih Dahulu (Rights Issue) 
HMETD adalah produk yang dinilai sesuai dengan kriteria DSN karena bersifat hak dan meleka dengan produk induknya. Mekanisme rights bersifat opsional dimana rights merupakan hak unutk membeli saham pada harga tertentu pada waktu yang telah ditetapkan.

6. Warran Syariah

Warran adalah produk turunan saham (derivatif) yang dinilai sesuai dengan kriteri DSN. Pemilik saham dengan imbalan (warran) diperbolehkan untuk mengalihkan kepemilikan sahamnya kepada orang lain dengan mendapat imbalan.

\section{Para Pelaku Pasar Modal}

a. Emiten

Emiten adalah perusahaan yang akan melakukan penjualan surat surat berharga atau melakukan emisi di bursa. Emiten dalam melakukan emisi dapat memilih dua instrumen pasar modal apakah bersifat

Kepemilikan atau utang. Jika bersifat kepemilikan maka diterbitkanlah saham dan jika bersifat utang maka yang dilpilih adalah obligasi.

Tujuan emisi adalah:

1) Untuk perluasan usaha

2) Untuk memperbaiki struktur modal

3) Untuk mengadakan pengalihan pemegang saham

4) Keterbukaan mendorong meningkatnya profesionalisme

5) Menurunkan kesenjangan sosial, karena peluang masyarakat menjadi investor besar

6) Sarana promosi

b. Investor

Pemodal yang akan membeli atau menanamkan modalnya di perusahaan yang melakukan emisi disebut investor. Sebelum membeli surat surat berharga yang ditawarkan para investor biasanya melakukan penelitian dan analisis analisis tertentu. Penelitian ini mencakup bonafiditas perusahaan, prospek usaha emiten, dan analisis lainnya. Adapun tujuan utama para investor dalam pasar modal antara lain:

1) Memperoleh dividen, yaitu keuntungan yang akan diperoleh investor yang dibayar oleh emiten 
2) Kepemilikan perusahaan, semakin banyak saham yang dimiliki, maka semakin besar pengusaha perusahaan

3) Berdagang, yaitu investor akan menjual kembali pada saat harga tinggi. Jadi pengharapannya adalah pada saham yang benar benar dapat menaikkan keuntungannya dari jual beli sahamnya

\section{c. Perusahaan Pengelola Data (Investment Company)}

Perusahaan pengelola dana merupakan perusahaan yang beroperasi di pasar modal dengan mengelola modal yang berasal dari investor. Perusahaan pengelola dana mempunyai dua unit yaitu pengelolaan dana (fund management) dan penyimpanan dana (custodian). Pengelola dana memutuskan efek mana yang harus dijual dan efek mana yang harus dibeli kemudian yang melaksanakan penjualan atau pembelian adalah kusodian. Kustodian juga melakukan penagihan keuntungan kepada emiten. Perusahaan pengelola dana menarik pemodal dapat melalui dana bersama (mutual fund), menerbitkan sertifikat yang didkung oleh efek efek yang dimilikinya, dan membentuk dana khusus melalui penjualan saham.

\section{d. Reksa Dana}

Reksa dana adalah wadah yang digunakan untuk menghimpun dana dari masyarakat pemodal untuk selanjutnya diinvestasikan dalam portofolio efek oleh manajer investasi. Dari definisi di atas reksa dana dapat dipahami sebagai suatu wadah dimana masyarakat dapat menginvestasikan dananya dan oleh pengurusnya, yaitu manajer investasi, dana tersebut diinvestasikan ke portofolio efek. Portofolio efek adalah kumpulan (kombinasi) sekuritas, surat berharga atau efek, atau instrument yang dikelola. Reksa dana syariah merupakan lembaga intermediasi yang membantu surplus unit melakukan penempatan dana untuk diinvestasikan. Salah satu tujuan dari reksa dana syariah adalah memenuhi kelompok investor yang ingin memperoleh pendapatan investasi dari sumber dan cara yang bersih dan dapat dipertanggung jawabkan secara agama serta sejalan dengan prinsip-prinsip syariah. Pada prinsipnya lembaga penunjang menawarkan atau menyediakan jasa baik bagi emiten maupn investor.

a. Lembaga Penunjang Pasar Perdana

1) Lembaga Penunjang untuk Emisi Saham

a) Penjaminan emisi efek (underwriter)

yaitu pihak yang membuat kontrak dengan emiten untuk melakukan penawaran umum bagi kepentingan emiten dengan atau tanpa keajiban untuk membeli sisa efek yang tidak terjual. 
b) Akuntan publik yang disahkan oleh BPKP, bertugasa anatara lain melakukan pemerikasaan atas laporan keuangan perusahaan dan memberikan pendapatanya, memerikasa pembukuan, apakah sudah sesuai dengan prinsip akuntansi Indonesia dan ketentuan Bapepam serta memberi petunjuk pelaksanaan cara cara pembukuan yang baik (apabila diperlukan).

c) Konsultan hukum, bertugas meneliti aspek aspek hukum emiten dan memberikan pendapat segi hukum (legal Opinion) tentang keadaan dan keabsahan usaha emiten, antara lain sebagai berikut:

(1) Anggaran dasar/akta pendirian perusahaan meliputi: pengesahan dari instansi yang berwenang,

pemodalan, pegurusan, dan hak -hak dan kewajiban para pemegang saham

(2) Penyertaan modal oleh pemegang saham sebelum go public.

(3) Izin usaha yang wajib dimiliki emiten

(4) Bukti pemilikan/penguasaan atas harta kekayaan emiten

(5) Perikatan perikatan yang dilakukan oleh emiten dengan pihak ketiga

(6) Gugatan atau tuntutan dalam perkara perdata atau pidana yang menyangkut emiten atau pribadi pengurus.

d) Notaris bertugas, antara lain:

(1) Membuat berita acara rapat umum pemegang saham (RUPS)

(2) Menyusun setiap keputusan dalam RUPS

(3) Meneliti keabsahan yang berkaitan dengan penyelenggaraan RUPS seperti keabsahan persiapan RUPS, keabsahan para pemegang saham

(4) Membuat konsep atas perubahan anggaran dasar

(5) Menyiapkan naskah perjanjian dalam rangka emisi efek

(e) Agen penjual yang umumnya adalah perusahaan efek, bertugas antara lain:

(1) Melayani investor yang akan memesan saham

(2) Melaksanakan pengembalian uang pesanan (refund) kepada investor

(3) Menyerahkan sertifikasi efek kepada pemesan (investor) Perusahaan penilai yang diperlukan apabila perusahaan emiten melakukan penilaian kembali aktiva nya.

2. Lembaga Penunjang untuk Emisi Obligasi 
a) Wali amanat (trustee) merupakan pihak yang mewakili kepentingan pemegang efek yang bersifat utang dan memiliki tugas antara lain:

(1) Menganalisis kemampuan dan kredibilitas emiten

(2) Melakukan penilaian terhadap sebagian atau seluruh harta kekayaan

emiten yang diterima olehnya sebagai jaminan

(3) Memberikan nasihat yang diperhitungkan oleh emiten

(4) Melakukan pengawasan terhadap pelunasan pinjaman pokok beserta imblannya (bunga bagi konvensional) yang harus dilakukan oleh emiten tepat pada waktunya.

b) Penanggung (gurantor), yang bertanggung jawab atas dipenuhinya pembayaran pinjaman pokok obligasi serta imbalannya.

c) Agen pembayaran (paying agent) yang bertugas membayar imbalan obligasi.

d. Lembaga Penunjang Pasar Sekunder Masa penawaran efek di pasar perdana ditentuka jangka waktu. Selesai masa penawaran efek tersebut dicatatkan (listing) di bursa efek. Setelah itu diperdagangkan

secara terus menerus dan harganya akan berfluktuasi. Transaksi efek ini disebut pasar sekunder dimana harga masing masing efek ditentukan oleh mekanisme pasar, yaitu

kekuatan permintaan dan penawaran atau suatu efek. Lembaga penunjang pasar sekunder merupakan lembaga yang menyediakan jasa -jasa dalam melaksanakan transaksi jual beli di bursa, terdiri atas:

1) Perusaahaan efek (securities company)

2) Pedagang Efek (dealer)

3) Perantara pedagang efek (broker/pialang)

4) Biro administrasi efek

Analisis Penawaran Efek Syariah di Pasar Modal Bagi perusahaan yang mencari dana segar, pasar modal menyediakan dana segar melalui mekanisme go public dengan menerbitkan saham dan menyediakan dana dari penjualan saham. Perusahaan dapat juga menerbitkan obligasi kepada masyarakat luas dan membayar imbalan yang lebih rendah daripada imbalan yang harus dibayar melalui pinjaman

perbankan. Penilaian suatu efek sangat dipengaruhi oleh kondisi kinerja keuangan perusahaan penerbitnya. Dalam analisis memilih efek ada beberapa teknik yang dapat dilakukan Penanaman pasar modal dapat dilakukan dengan 2 cara : 
a. Transaksi di Pasar Perdana Bagi investor yang ingin membeli saham di pasar perdana haruslah menggunakan pertimbanganpertimbangan yang bersumber dari kondisi perusahaan yang mengeluarkan efek tersebut melalui prospektur yang memberikan informasi dari catatan keuangan historis sampai proyeksi laba dan dividen yang akan dibayarkan untuk tahun berjalan. Umumnya dilihat apakah proyeksi pertumbuhan perusahaan tersebut melampaui rata-rata pertumbuhan industry sejenis. Di samping itu, bonafiditas lembaga dan profesi yang menunjang penerbitan efek yang diperhatikan seperti penjamin emisi (underwriter) wali amanat, agen penjualan, penanggung, akuntan public, perusahaan penilaian (appraisal) konsultan hukum, notaris. Bagi investor muslim, tentu lebih didorong untuk memilih emitem yang telah terdaftar dalam listing JII (Jakarta Islamic Index) sebagai instrument keuangan syariah.

Adapun prosedur pembelian efek di pasar perdana secara umum:

1. Pembeli menghubungi agen penjualan yang ditunjuk oleh underwriter (penjamin emisi) untuk mengisi

formulir pemesanan. Formulir pemesanan yang telah diisi oleh

investor dikembalikan kepada agen penjualan disertai dengan tanda tangan dan kopian kartu identitas investor serta jumlah dana sesuai dengan nilai efek yang dipesan. Formulir pemesanan biasanya berisi informasi tentang harga efek, jumlah efek yang dipesan, indentitas pemesanan, tanggal penjatahan dan pengembalian dana jika kelebihan permintaan jumlah yang dibayarkan, agen penjualan yang dihubungi dan cara pemesanan. Satuan yang dipakai dikenal dengan istilah lot, di mana satu lot saham di Indonesia saat ini mewakili 500 lembar saham dan kelipatan harga saham disebut point. 


\section{KESIMPULAN}

Indek syariah telah menjadi bagian atau instrument dalam transaksi dipasar modal. Setiap surat berharga yang masuk dipasar modal syariah arus melalui seleksi yang ketat pada indekk syariah yaitu JII (Jakarta Islamic Indeks). Seleksi tersebut merupakan bagian proses penawaran efek syariah sebelum

ditawarkan kepada investor melalui pasar modal. Diantara indek syariah yang selalu dimanati di tingkat investor adalah saham syariah, reksadana syariah, obligasi syariah (SUKUK) yang merupakan bagian yang tidak dapat dipisahkan dalam transaksi dipasar modal. Lembaga ini memberikan syarat terhadap efek

syariah dengan usaha utama tidak bertentangan dengan syariat islam yang diatur melalui fatwa DSN-MU. Dengan keberadaan Index syariah ini, maka Bank Islam, Takaful, dan lembaga keuangan syariah lainnya memiliki alternatif untuk menginvestasikan dana mereka dan mendistribusikan keuntungan mereka kepada nasabah-nasabah mereka. 


\section{DAFTAR PUSTAKA}

Firdaus, dkk. 2005. Briefcase Book Edukasi Profesional Syariah: Sistem Keuangan \& Investasi Syariah. Jakarta: Renaisan.

Huda, Nurul dan Mustofa Edwin Nasution. 2008. Investasi Pada Pasar Modal Syariah. Jakarta:

Kencana. 